\title{
Bifunctional protein required for asymmetric cell division and cell-specific transcription in Bacillus subtilis
}

\author{
Andrea Feucht, ${ }^{1}$ Thierry Magnin, ${ }^{2}$ Michael D. Yudkin, ${ }^{2}$ and Jeffery Errington ${ }^{1,3}$ \\ ${ }^{1}$ Sir William Dunn School of Pathology and ${ }^{2}$ Biochemistry Department, University of Oxford, Oxford OX1 3RE, \\ England, UK
}

\begin{abstract}
During sporulation in Bacillus subtilis an asymmetric cell division gives rise to unequal progeny called the prepore and the mother cell. Gene expression in the prespore is initiated by cell-specific activation of the transcription factor $\sigma^{F}$. Three proteins participate in the regulation of $\sigma^{F}$ activity. The first, SpoIIAB, is an inhibitor of $\sigma^{\mathrm{F}}$, that is, an anti- $\sigma$ factor. SpoIIAB is also a protein kinase that catalyzes phosphorylation of the second regulatory protein SpoIIAA (the anti-anti-o factor), and thus inactivates it. $A$ third protein, SpoIIE, was shown recently to be able to dephosphorylate SpoIIAA-P in vitro. Here we show that SpoIIE is a bifunctional protein with two critical roles in the establishment of cell fate. First, we confirm by the use of in vivo experiments that it regulates the release of $\sigma^{F}$ activity by dephosphorylating SpoIIAA-P. Second, we show that SpoIIE is needed for normal formation of the asymmetric septum that separates the prespore from the mother cell. Combination of these two functions in a single polypeptide may serve to couple the release of the cell-specific transcription factors with the formation of the differentiating cells.
\end{abstract}

[Key Words: Sporulation; phosphorylation; Bacillus subtilis; $\boldsymbol{\sigma}$-factor; anti- $\boldsymbol{\sigma}$-factor; septation; asymmetric cell division; phosphatase]

Received January 3, 1996; revised version accepted February 6, 1996.

The generation of cells with distinct developmental fates is a fundamental problem in almost all developmental systems. Frequently, cell fate is specified by an asymmetry that occurs at the time of division (Horvitz and Herskowitz 1992). In the rod-shaped, Gram-positive bacterium Bacillus subtilis vegetative (proliferative) cell division occurs by medial division to produce two identical progeny. After starvation, however, the cell cycle is modified and a highly asymmetric division occurs. In the resulting two cells-the small prespore and the large mother cell-different transcription factors are activated, and these initiate an intricate developmental program. Ultimately, the prespore matures into a tough, dormant spore. The mother cell contributes much of its resources to the development of the spore but eventually lyses (for review, see Losick and Stragier 1992; Errington 1993).

The transcription factor $\sigma^{\mathrm{F}}$ plays a pivotal role in the determination of cell fate during sporulation. It not only activates the prespore-specific program of gene expression but also triggers an intercellular signal that specifies the fate of the mother cell by activating therein a different transcription factor, $\sigma^{\mathrm{E}}$ (for review, see Errington 1996). Some features of the mechanism whereby $\sigma^{\mathrm{F}}$ activity is regulated are now known. The protein begins to

\footnotetext{
${ }^{3}$ Corresponding author.
}

be synthesized before septation /Gholamhoseinian and Piggot 1989; Min et al. 1993; Partridge and Errington 1993), so its product presumably passes into both the prespore and the mother cell. It is prevented from becoming active, except in the prespore, by an inhibitor (anti- $\sigma$ factor) called SpoIIAB (Duncan and Losick 1993; Min et al. 1993). In turn, SpollAB is antagonized by an anti-anti- $\sigma$ factor, SpoIIAA (Alper et al. 1994; Diederich et al. 1994). SpoIIAA and SpoIIAB can interact in two different ways, at least in vitro. In the presence of ADP, the two proteins form a complex, with the result that SpoIIAB is prevented from inhibiting $\sigma^{\mathrm{F}}$ (Alper et al. 1994; Diederich et al. 1994). However, SpoIIAB is also a protein kinase, which, in the presence of ATP, phosphorylates SpoIIAA on a single serine residue (Min et al. 1993). Phosphorylation of SpoIIAA leads to a large conformational change that prevents it from interacting further with SpoIIAB (Magnin et al. 1996). A change in the ATP/ADP ratio in vivo has been postulated to be the physiological trigger for release of $\sigma^{\mathrm{F}}$ in the prespore (Alper et al. 1994; Diederich et al. 1994). However, the phosphorylation of SpoIIAA by SpoIIAB is a rapid and quantitative reaction, at least in vitro; therefore, we have suggested that the regeneration of nonphosphorylated SpoIIAA by a phosphatase might be essential for the release of $\sigma^{\mathrm{F}}$ activity in vivo (Diederich et al. 1994; Magnin et al. 1996). 
Similar in many ways to $\sigma^{\mathrm{F}}$ is a second $B$. subtilis $\sigma$ factor, $\sigma^{\mathrm{B}}$, that controls a general stress response (Benson and Haldenwang 1993b; Boylan et al. 1993; Völker et al. 1994). $\sigma^{\mathrm{B}}$ is also regulated by anti- $\sigma$ and anti-anti- $\sigma$ factors (Boylan et al. 1992; Benson and Haldenwang 1993a; Dufour and Haldenwang 1994), and it responds unequivocally to a reduction in energy charge. Treatment of cells with uncouplers of oxidative phosphorylation can cause immediate and strong release of $\sigma^{\mathrm{B}}$ activity in vegetative cells (Alper et al. 1994). In similar experiments, $\sigma^{\mathrm{F}}$ activity was also released, but the response was weak and delayed by several hours (Alper et al. 1994). This result suggests that nucleotide levels may help to control $\sigma^{\mathrm{F}}$ but that another factor, such as a phosphatase, might also be required. A candidate for such a factor would be the product of the spoIIE gene; mutations in this gene block $\sigma^{\mathrm{F}}$-dependent gene expression at the level of $\sigma^{\mathrm{F}}$ activity (Margolis et al. 1991). Moreover, the carboxyterminal part of SpoIIE has been found recently to have significant sequence similarity to RsbU (Duncan et al. 1995; Errington et al. 1996), a protein implicated in the regulation of $\sigma^{\mathrm{B}}$ (Völker et al. 1995; Wise and Price 1995). Recent work has shown that the purified carboxy-terminal region of SpoIIE is a phosphatase that can dephosphorylate SpoIIAA-P in vitro (Duncan et al. 1995) and that in sporulating cells, the protein localizes to the incipient sites of asymmetric septation (Arigoni et al. 1995).

Here we show that mutations in the spoIIE gene block $\sigma^{\mathrm{F}}$ activity by preventing the dephosphorylation of SpoIIAA in vivo, providing support for the view that the product of the spoIIE gene is a phosphatase. We also show that in nonsporulating cells engineered to produce SpoIIAA, SpoIIAB, and $\sigma^{\mathrm{F}}$, the release of $\sigma^{\mathrm{F}}$ activity is strongly stimulated by cosynthesis of SpoIIE and that this stimulation is associated with increased accumulation of nonphosphorylated SpoIIAA. Until now, interpretation of the role of SpoIIE has been complicated by the knowledge that some spolle mutants not only fail to activate $\sigma^{\mathrm{F}}$ but also have aberrant spore septa (Piggot 1973; Illing and Errington 1991). Because $\sigma^{\mathrm{F}}$ activation depends on formation of the spore septum (Margolis 1993), it had seemed possible that the effect of spoIIE mutations on $\sigma^{\mathrm{F}}$ activity might be indirect. We have resolved this complication by showing that SpoIIE has, independent of its role in dephosphorylation of SpoIIAA, a second separable function required for correct formation of the asymmetric septum. Therefore, the protein combines both regulatory and morphogenic functions in a single polypeptide. It has been shown independently (F. Arigoni, L. Duncan, S. Alper, R. Losick, and P. Stragier, pers. comm.) that the ratio of phosphorylated to nonphosphorylated SpoIIAA in the cell is governed by the presence and abundance of SpoIIE.

\section{Results}

spoIIE mutations block the accumulation of nonphosphorylated SpoIIAA in vivo

To test the importance of the carboxy-terminal RsbU- like region of SpoIIE for $\sigma^{\mathrm{F}}$ activation in vivo, we constructed two new insertional spoIIE mutations. One mutation (spoIIE1302) is an insertion in the heart of the rsbU-like region; the other (spoIIE1301) lies just beyond the conserved region (Fig. $1 \mathrm{~A}$ ). A $\sigma^{\mathrm{F}}$-dependent reporter gene (gpr-lacZ) was introduced into the two mutants, and the levels of $\beta$-galactosidase activity in cultures resuspended in sporulation medium were compared with those of a wild-type control. As shown in Figure 1B, the insertion disrupting SpoIIE in the middle of the RsbUlike domain completely abolished the release of $\sigma^{\mathrm{F}}$ activity, whereas $\beta$-galactosidase activity was more or less normal in the mutant in which the conserved region remains intact (1301). Therefore, it appears that the conserved RsbU-like domain of SpoIIE is important for the regulation of $\sigma^{\mathrm{F}}$ in vivo. To determine whether the spoIIE1302 mutation blocked $\sigma^{\mathrm{F}}$ activation by preventing the dephosphorylation of SpoIIAA-P, we made extracts of resuspended cultures of the three strains and used anti-SpoIIAA antibodies to measure the content of phosphorylated and nonphosphorylated SpoIIAA (Fig. 1C-E). As expected on the basis of previous studies (Min et al. 1993; Partridge and Errington 1993), in the wildtype culture little protein of either form was detected at the onset of sporulation but synthesis was strongly induced from $\sim 60 \mathrm{~min}$. Most of the protein was phosphorylated, in accordance with our previous finding that the phosphorylation reaction is extremely efficient in vitro (Diederich et al. 1994). However, nonphosphorylated SpoIIAA was also readily detected at all times from 60 min. Similar results were obtained in extracts of the spoIIE1301 mutant (Fig. 1D). In contrast, nonphosphorylated SpollAA was virtually undetectable in the spollE1302 mutant background (Fig. 1E), in which $\sigma^{\mathrm{F}}$ activation is abolished (Fig. 1B). We do not know why both spoIIE mutants synthesize increased amounts of SpoIIAA relative to the wild type, but the clear presence of nonphosphorylated SpoIIAA in extracts of the spoIIE1301 mutant, but not in those of the spoIIE1302 mutant, supports the idea that the RsbU-like domain of SpoIIE releases $\sigma^{\mathrm{F}}$ activity by catalyzing the dephosphorylation of SpoIIAA-P.

\section{Release of $\sigma^{F}$ activity in nonsporulating cells by coinduction of the spoIIA and spoIIE operons}

Previously, two groups have reported that induction of the spoIIA operon (encoding $\sigma^{\mathrm{F}}$, the anti- $\sigma$ SpoIIAB and the anti-anti- $\sigma$ SpoIIAA) in vegetative cells results in expression of $\sigma^{\mathrm{F}}$-dependent genes (Schmidt et al. 1990; Partridge et al. 1991). However, expression was much weaker than in sporulating cells, which suggested that some other factor, present in sporulating but not vegetative cells, might be needed for optimal $\sigma^{\mathrm{F}}$ activation. To determine whether SpoIIE was the additional factor and to confirm its postulated role in the dephosphorylation of SpollAA-P, we constructed a strain in which the spoIIE gene was controlled by a xylose-inducible promoter. This construction was then introduced into a 
Figure 1. Structure of the spoIIE gene and the effects of spoIIE mutations on the regulation of $\sigma^{\mathrm{F}}$ and the accumulation of nonphosphorylated SpoIIAA. (A) The spolIE gene product and sites of certain mutations affecting either septation or $\sigma^{\mathrm{F}}$ activation. $(B)$ Effects of spoIIE mutations on $\sigma^{\mathrm{F}}$ activation. Strains SG38 $(\square$, wild type), 71.2 ( $\times$, spollE71); 1301 10, spollE::aphA3), $1302(\triangle$, spoIIE::erm $C)$, and $1.5(\diamond$, spoIIAC1), all containing a $g p r-l a c Z$ reporter plasmid (pSG1326) integrated into their chromosome, were induced to sporulate and assayed at intervals for $\beta$-galactosidase activity. $(C-E)$ Accumulation of nonphosphorylated SpoIIAA in sporulating cells of wild-type and spoIIE strains of $B$. subtilis. Strains SG38 (wild type) (C) 1301 (spoIIE::aph-A3) (D), and 1302 (spoIIE::ermC) $\langle E\rangle$ were induced to sporulate and at the time points indicated (minutes after induction of sporulation) samples were taken, the cells were broken, and the proteins were separated by nondenaturing PAGE. The proteins were tranferred to nitrocellulose and probed with antiSpoIIAA antibodies (which detect both SpoIIAA and SpoIIAA-P). The arrows show the position of purified SpoIIAA $|A A|$ and SpolIAA-P (AA-P) run in adjacent lanes on the same gels.

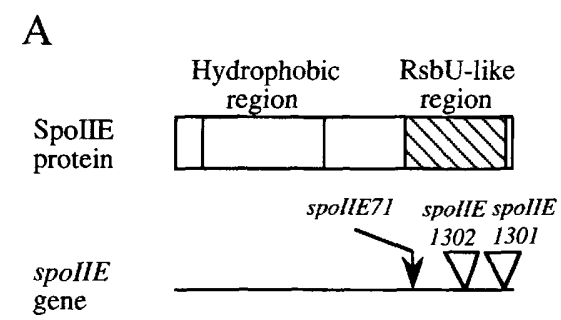

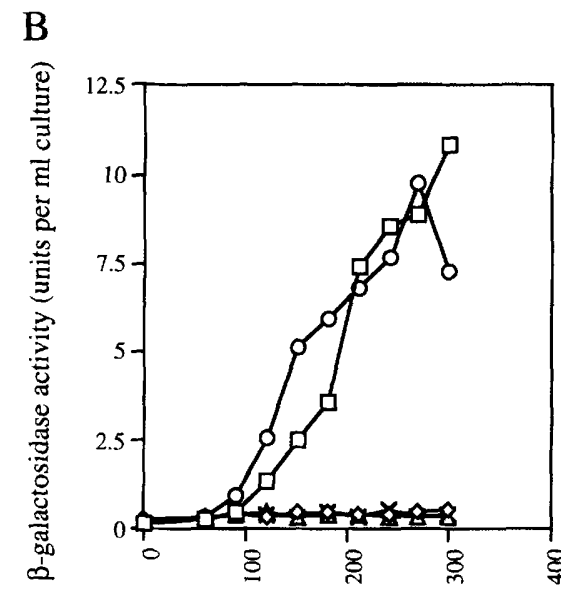

Time (mins) after resuspension

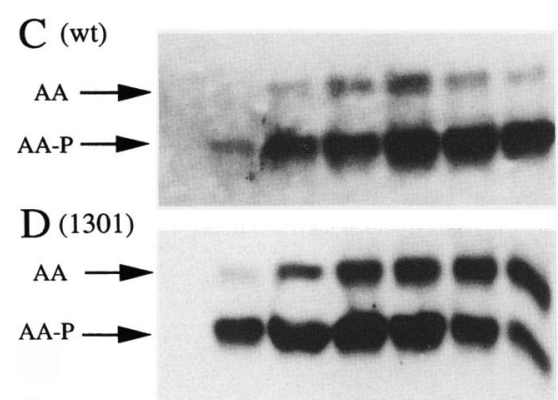

E (1302)

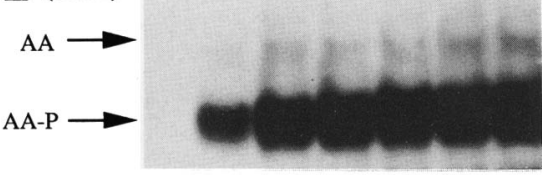

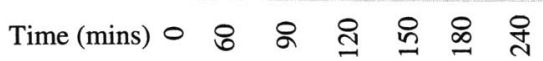

strain used previously to test for $\sigma^{\mathrm{F}}$ activation in vegetative cells (Partridge et al. 1991).

Strain 1304 contains a $\sigma^{\mathrm{F}}$-dependent reporter gene, the xylose-inducible spoIIE gene, and the IPTG-inducible spoIIA operon construct of Partridge et al. (1991). The strain was grown in per assay broth $(\mathrm{PAB})$, a rich medium in which sporulation does not occur. The culture was divided into four portions, and inducers were added separately or in combination. As shown in Figure 2A, there was no detectable $\sigma^{\mathrm{F}}$ activity in the control strain without inducers nor in the culture in which spoIIE only was induced. In the culture with IPTG added (spoIIA inductionl, a weak transient induction of the $\sigma^{F}$-dependent lac $Z$ gene occurred, as described previously (Partridge et al. 1991). However, with both inducers added, a large increase in $\beta$-galactosidase activity occurred, indicating that SpoIIE enhances the release of $\sigma^{\mathrm{F}}$ activity under these conditions.

Figure $2 \mathrm{~B}$ shows that neither form of SpoIIAA was produced to a significant extent in the absence of IPTG, the inducer for the spoIIA operon. When the spollA operon was induced in the absence of spoIIE (Fig. 2C), a situation in which low-level $\sigma^{\mathrm{F}}$ activation occurred (Fig. 2A), SpollAA was readily detected and almost all was in the phosphorylated form. When spoIIE was also induced similar amounts of SpoIIAA were synthesized, but the protein migrated almost exclusively in the position of the nonphosphorylated form (Fig. 2D). Thus, the increase in $\sigma^{\mathrm{F}}$ activity produced by induction of SpoIIE is associated with greatly increased accumulation of the nonphosphorylated form of SpoIIAA.

\section{Asymmetric septation is delayed in some spollE} mutants

The finding of a specific role for SpoIIE in the regulation of $\sigma^{\mathrm{F}}$ left previous electron microscopical observations unexplained, indicating that some spoIIE mutants have aberrantly thick but correctly positioned spore septa (Piggot 1973; Illing and Errington 1991). To investigate the septation defect of spoIIE mutants in more detail, we took advantage of a recently developed light microscopic method to visualize asymmetric septa (Hauser and Errington 1995/. In preliminary experiments, this method was used to study a collection of 11 previously isolated and newly constructed spoIIE mutants. Surprisingly, in several of the strains completion of asymmetric septation was clearly delayed, and many cells seemed to fail altogether to make a septum. In accordance with our previous demonstration that prespore chromosome partitioning is dependent on asymmetric septation (Wu et al. 1995), these mutants also exhibited a partitioning defect (see also Pogliano et al. 1995). 


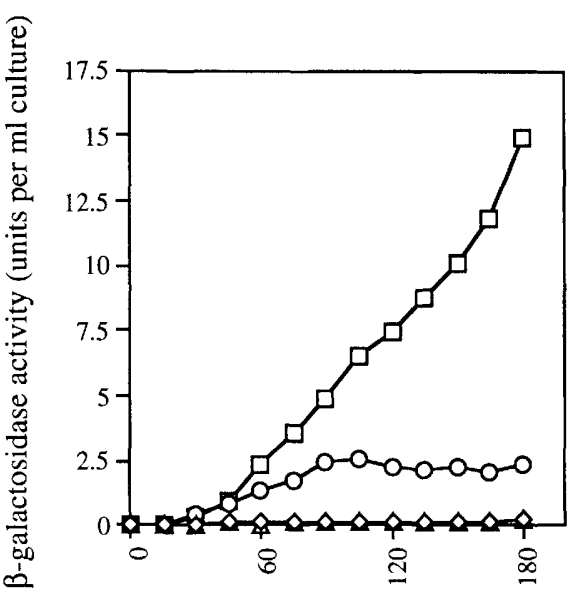

Time (mins) after induction

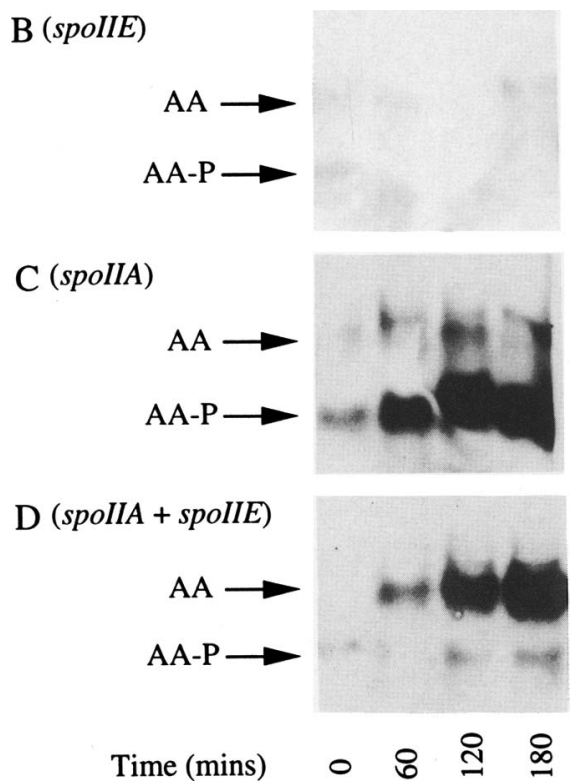

Figure 2. Release of $\sigma^{\mathrm{F}}$ activity in vegetative cells by coinduction of the products of the SpoIIA opcron and the spoIIE gene. (A) Strain 1304 was grown in PAB to mid-exponential phase and divided into four portions. At $t_{0}$ inducers were added as indicated and $\beta$-galactosidase activity was followed in each culture. $(\diamond)$ No inducer; $(\triangle)$ xylose; $(O) I_{\text {IPTG; }}(\square)$ xylose + IPTG. $(B-D)$ Samples were taken from the cultures described in $A$ at the time points shown (min) and processed to detect the levels of phosphorylated and nonphosphorylated SpoIIAA as described in the legend to Fig. 1. $(B)$ Xylose only; $(C)$ IPTG only; $(D)$ xylose + IPTG. Arrows indicate the positions of phosphorylated and nonphosphorylated SpoIIAA (AA-P and AA, respectively).

Detailed time courses for septation in several mutants are shown in Figure 3A. In the newly constructed strain with an insertion disrupting the RsbU-like domain (1302), the time at which completed septa were first detected was delayed by $\sim 20 \mathrm{~min}$, and the overall rate of septation was reduced; therefore, the final yield of septa was only $\sim 50 \%$ of the wild type. This phenotype was not attributable to the loss of $\sigma^{\mathrm{F}}$ activation because strain 690 , which has a nonsense mutation in the gene encoding $\sigma^{\mathrm{F}}$ (Yudkin 1987), showed normal kinetics of septation (Fig. 3A) and normal chromosome partitioning (not shown).

Some spo mutants, after making one polar septum at the normal time, continue $\sim 20$ min later to make a second septum at the opposite pole of the cell (Lewis et al. 1994). The disporic phenotype occurs in mutants that can progress to stage II of sporulation (septation) but cannot synthesize or activate the mother cell $\sigma$ factor $\sigma^{\mathrm{E}}$ (Lewis et al. 1994). Because the spoIIE1302 mutation blocks $\sigma^{\mathrm{F}}$ activation and $\sigma^{\mathrm{F}}$ is required for $\sigma^{\mathrm{E}}$ activation (Margolis et al. 1991; Karow et al. 1995; Londoño-Vallejo and Stragier 1995), this mutant would be expected to exhibit a disporic phenotype. However, as shown in Figure $3 \mathrm{~B}$, the incidence of disporic cells in strain 1302 was greatly reduced, compared with strain 690 , which carries a mutation in spoIIAC and is a typical disporic mutant. This result provides a further indication that septation is severely impaired in the spoIIE1302 mutant.

Electron microscopic examination of sporulating cells of strain 1302 (Fig. 3D) showed that it makes thick, morphologically abnormal spore septa similar to those described previously for strains containing some spoIIE mutations, such as spoIIE21 (Illing and Errington 1991). For comparison, a typical thin septum from strain 690 (similar to that of the wild type) is shown in Figure 3C. Disruption of the RsbU-like domain of SpoIIE therefore not only blocks $\sigma^{\mathrm{F}}$ activation but also affects both the timing and morphology of polar septa.

Isolation of mutations that dissociate the roles of SpollE in septation and $\sigma^{F}$ activation

Surprisingly, examination of the septation frequency in the spoIIE1301 mutant, in which $\sigma^{\mathrm{F}}$ activation appeared nearly normal (see above), revealed a defect as severe as that of the spoIIE1302 mutant, in which $\sigma^{\mathrm{F}}$ activation is blocked (Fig. 3A). Electron microscopy confirmed that the septation frequency was reduced and revealed septa with abnormal thickness (not shown). The defect in septation probably explains the reduced number of spores formed by this mutant $(\sim 20 \%$ of that of the wild type). The finding of a mutant in which septation was impaired, but $\sigma^{F}$ activation was not blocked, suggested that the SpoIIE protein has two distinct and separable functions. If these functions were independent, it should be possible to isolate a third class of mutant, which would be affected in $\sigma^{\mathrm{F}}$ activation but not in septation. Such mutants might differ from the spoIIE mutants described above in conferring a classic disporic phenotype, similar to that of the spoIIAC mutant strain 690 . In our preliminary light microscopic experiments mentioned above, the strain carrying the spoIIE71 mutation showed the highest proportion of disporic cells of the mutants we 
Figure 3. Delay and aberrant construction of asymmetric septa in spoIIE mutants. $(A)$ Time of formation of the spore septum as measured by phase-contrast microscopy of ethanol-fixed preparations. Strains SG38 ( $\square$ wild type), 71.2 ( $\times$, spoIIE71), 690 ( $\diamond$ spoIIAC1), 1301 (O spoIIE::aph-A3), and $1302(\triangle$ spoIIE::erm $C)$ were induced to sporulate and the proportion of cells with completed spore septa was determined. $(B)$ Proportions of cells exhibiting a disporic appearance, with a septum at both cell poles, in the same experiment as in $A .(C-E)$ Electron micrographs of thin sections of typical cells harvested for fixation and sectioning 180-210 min after the induction of sporulation. The strains used were as follows: $690(C) ; 1302(D)$; $71.2\{E)$.

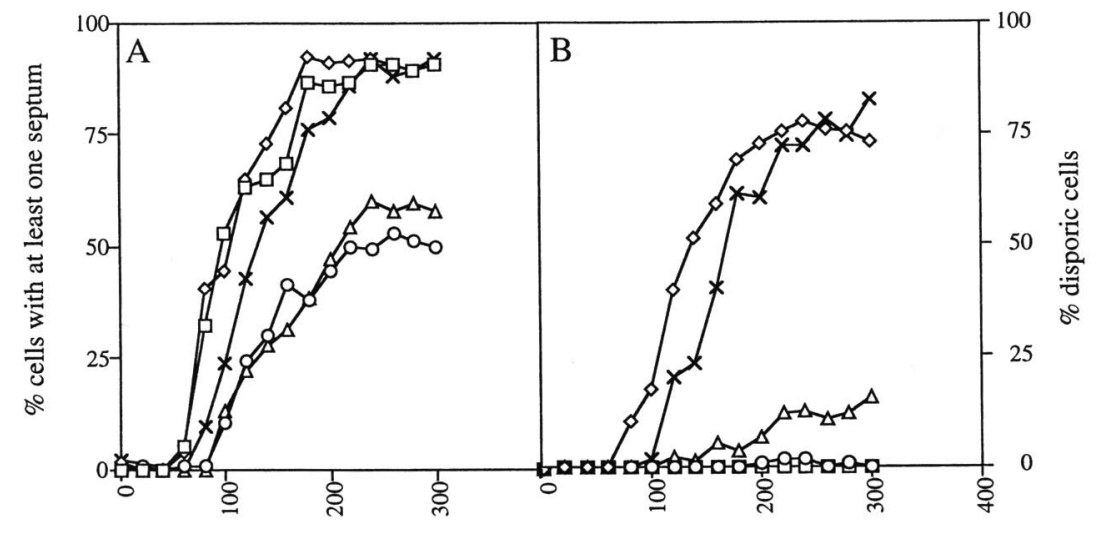

Time (mins) after resuspension

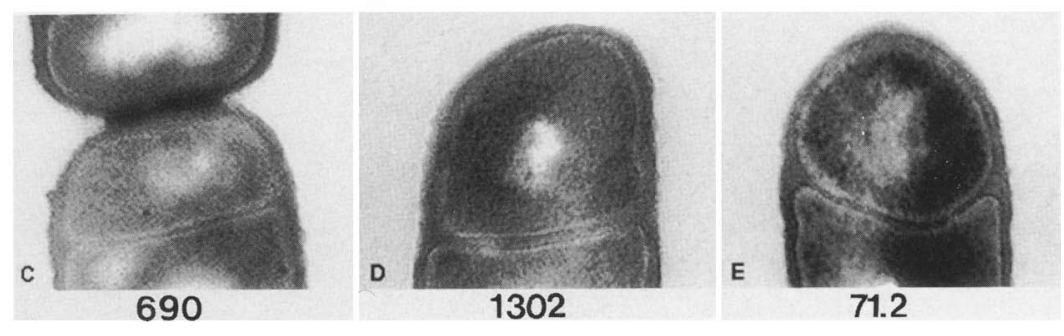

tested. As shown in Figure 3A, detailed measurements revealed that the septation frequency of this mutant is near normal, and it produced a far greater proportion of disporic cells than the other spoIIE mutants examined (Fig. 3B). Furthermore, electron microscopic examination of sporulating cells of the spoIIE71 mutant (Fig. 3E) confirmed that it makes thin septa, indistinguishable from those of the wild type or the spoIIA mutant, but quite different from those of the spoIIE mutants that show impaired septation kinetics. Although septation appeared to be almost normal in this mutant, $\sigma^{\mathrm{F}}$ activation was blocked, as in all of the other spoIIE mutants tested, except strain 1301 (Fig. 1B). Moreover, examination of the SpoIIAA made in resuspended cultures of this strain showed that normal quantitites of SpoIIAA-P were present but that nonphosphorylated SpoliAA could not be detected (results not shown).

The spoIIE71 mutation from strain 71.2 was sequenced and found to be a G:C to A:T missense mutation that would change a conserved glycine residue /Gly609 ) in the RsbU-like domain of SpolIE to aspartate. We conclude that this carboxy-terminal domain of SpoIIE is required specifically for $\sigma^{F}$ activation and that it is embedded within a protein that has a second, independent function required for proper asymmetric division.

\section{Discussion}

The interactions among SpoIIAA, SpoIIAB, and $\sigma^{F}$ have been well characterized in the past few years. Although $\sigma^{\mathrm{F}}$ activity can be released in vitro by modulating the levels of adenosine nucleotides, we had several reasons (mentioned above) for believing that an additional factor might be needed for $\sigma^{\mathrm{F}}$ activation in vivo. The spoIIE gene was a likely candidate for such a factor because mutations in this gene were known to block $\sigma^{F}$ activation (Margolis et al. 1991). The finding of significant sequence similarity between the carboxy-terminal domain of SpoIIE and the RsbU protein implicated in the regulation of $\sigma^{\mathrm{B}}$ (Völker et al. 1995; Wise and Price 1995) strongly supported this idea. Therefore, we constructed and characterized a mutation that would disrupt the RsbU-like domain of SpoIIE (strain 1302). As expected, the mutation blocked $\sigma^{F}$ activation. Development of a method for determining the relative levels of phosphorylated and nonphosphorylated SpoIIAA in vivo allowed us to show that the block in $\sigma^{\mathrm{F}}$ activation was associated with a lack of nonphosphorylated SpoIIAA (Fig. 1). Another insertion in the spoIIE gene, placed just after the last conserved codon (strain 1301), blocked neither $\sigma^{\mathrm{F}}$ activation nor the accumulation of nonphosphorylated SpollAA (Fig. 1). As a positive means of associating phosphatase activity in vivo with the SpolIE protein, we constructed a strain of $B$. subtilis in which we could induce separately the products of the SpoIIE and spoIIA operons in vegetative cells. Induction of both operons led to a much greater increase in $\sigma^{\mathrm{F}}$ activity than induction of the spoIIA operon only, and the increase in $\sigma^{\mathrm{F}}$ activity was accompanied by a large increase in the proportion of nonphosphorylated SpoIIAA (Fig. 2D). This close correlation between $\sigma^{\mathrm{F}}$ activity and the proportion of nonphosphorylated SpoIIAA, in both vegetative and sporulating cells, strongly suggests that the RsbU-like domain of SpoIIE effects $\sigma^{F}$ activation by dephosphorylation of SpoIIAA-P in accordance with the function discovered for it in vitro (Duncan et al. 1995). 
The finding of a specific regulatory role for SpoIIE raised the question of the significance of the previously reported effects of some spoIIE mutations on asymmetric septation (Piggot and Coote 1976; Illing and Errington 1991). Although these previous electron microscopic studies had shown that some spoIIE mutants have aberrantly thick septa, the kinetics of septation had not been investigated systematically. Development of a new light microscopic method has now enabled us to study the kinetics and has revealed a delay of $\geqslant 20 \mathrm{~min}$ in the time that completed septa begin to be detected in spoIIE mutants such as 1301 and 1302, compared with wild-type cells or cells of other stage II mutants, such as strain 690 . The delay in septation was accompanied by a reduction in the overall number of completed septa. The failure to detect a reduced septation frequency in the previous electron microscopic studies of Illing et al. (1991) most likely reflects technical differences between the methods used. For example, with electron microscopy both complete and incomplete septa can be detected, whereas with the phase-contrast method, which seems to rely on plasmolytic shrinkage of the cytoplasm, only completed septa become visible. Our confidence in the phase-contrast method for detection of completed septa was increased by the observation (Pogliano et al. 1995; A. Feucht, unpubl.) that spoIIE mutants are deficient in prespore chromosome partitioning. We have shown previously that prespore chromosome partitioning is dependent on completion of the spore septum (Wu et al. 1995). The precise role of the SpoIIE protein in septation remains to be clarified, but the finding that the protein is targeted to the sites of incipient septation (Arigoni et al. 1995 ) suggests that it interacts directly with the division apparatus.

Piggot (1973) reported that some mutants now known to be affected in the spoIIE locus exhibit a disporic phenotype, in contrast to the thick septum phenotype discussed above. The light microscopic methods allowed us to reassess the septation phenotypes of a collection of spolIE mutants. Although almost all showed at least a partial impairment in septation, we found that the spoIIE71 mutation allows formation of spore septa with almost normal kinetics. Thus, this mutant at least seems not to be affected in septation. Nevertheless, in accordance with our observation that it is a missense mutation affecting a conserved residue in the regulatory, RsbU-like domain of the SpoIIE protein, spollE71 completely blocked $\sigma^{\mathrm{F}}$ activity. This phenotype is essentially the opposite of the one exhibited by spoIIE1301, in which septation is impaired but the kinetics of $\sigma^{\mathrm{F}}$ activation are more or less normal. (At present, we are investigating the surprising finding that $\sigma^{\mathrm{F}}$ is activated at the normal time in mutant 1301, despite the delay in septation.) The finding of spoIIE mutants with these contrasting phenotypic effects strongly suggests that the SpoIIE protein has two distinct and independent functions: (1) a morphogenic activity needed for the formation of the separate prespore and mother cell compartments, and (2) a regulatory activity needed for release of the critical first cell-specific $\sigma$ factor $\sigma^{\mathrm{F}}$ in the prespore.
The combination of these two functions in a single polypeptide may provide another example of a mechanism that couples morphogenesis and transcriptional regulation during sporulation. Other postulated examples include the coupling of $\sigma^{\mathrm{G}}$ activation to the completion of prespore engulfment (Stragier 1992; Partridge and Errington 1993/ and the coupling of $\sigma^{\mathrm{K}}$ activation to a later step in prespore morphogenesis (Cutting et al. 1990). Clearly, such mechanisms may prove to be of general importance in developmental systems.

How might the incorporation of the phosphatase domain into a polypeptide involved in initiation of asymmetric septation facilitate the regulation of $\sigma^{\mathrm{F}}$ activity? It is possible that the role of SpollE is temporal, allowing $\sigma^{\mathrm{F}}$ to be activated only after the completion of septation. In this case, some other factor, such as an increase in the ADP/ATP ratio, could determine prespore localization of $\sigma^{\mathrm{F}}$ activity (Alper et al. 1994; Diederich et al. 1994). However, because the SpoIIE protein is targeted to the septum (Arigoni et al. 1995), asymmetric partitioning or activation of the protein in the septum could help to control $\sigma^{\mathrm{F}}$ localization (Fig. 4). In Figure 4A we suppose that at the completion of septation SpoIIE has become equally distributed on both faces of the spore septum, as suggested previously by Duncan et al. (1995). Localized activation of $\sigma^{\mathrm{F}}$ in the prespore might then occur as a result of the much higher effective concentration of the phosphatase in the small prespore compartment compared with the mother cell compartment (Arigoni et al. 1995). In Figure 4B we consider the possibility that SpoIIE is distributed throughout the prespore septum but its phosphatase activity is activated specifically in the prespore compartment (see also Duncan et al. 1995). This seems unlikely, given that the vegetatively produced SpoIIE protein seems to be active in the experiment shown in Figure 2, where there is no prespore-like compartment. A third possibility (Fig. 4C) is that the formation of the septum might actively drive the SpoIIE molecules originally targeted to the site of initiation of septation to the prespore side of the completed septum. The formation of the septum requires the synthesis of a great deal of new lipid, an amount corresponding approximately to two discs of the diameter of the parent cell. It seems reasonable to assume that much, if not all, of this new lipid would be synthesized in the much larger mother cell compartment. If so, there should be a large net flow of lipid through the annulus of the developing septum. Therefore, it is thus conceivable that most of the SpoIIE protein molecules participating in the onset of septation may end up, as a result of this flow, in the inner leaf of the prespore septum. There would then be a much higher concentration of the phosphatase in the small compartment.

\section{Materials and methods}

Bacterial strains and plasmids

The B. subtilis strains and plasmids used in this study are described in Table 1. Strain 1303 was constructed by tranforming 
the following ligation into SG38 and selecting for resistance to chloramphenicol $(5 \mu \mathrm{g} / \mathrm{ml})$. A 1.029 -kbp PCR fragment containing the sequence upstream of the spoIIE - 10 region was digested with BamHI and a 957-bp PCR fragment containing the sequence downstream of the spollE -10 region was digested with XbaI. Both fragments were ligated to BamHI-XbaI-digested pRD96. This generated some linear molecules in which the cat gene and the $\mathrm{P}_{x y l}$ promoter were flanked by the PCR fragments. The following oligonucleotides were used: 5'-GTTGTCATCAGACCGGCAGAGC-3'; 5'-CTAGTCTAGAAATGACAGGCAACG-3' (generating a $X b a$ I restriction site at the $5^{\prime}$ end of the fragment); and 5'-ACAGAGCTTGCCAGAAGGGAC-3'; 5'-CGCGGATCCATAGCGAAAGCAC-3' (generating a $B a m H I$ restriction site at the $3^{\prime}$ end of the fragment). Strain 1304 was constructed by tranforming chromosomal DNA from strain 1303 into strain 693, with selection on plates containing chloramphenicol $(5 \mu \mathrm{g} / \mathrm{ml})$, erythromycin $(1 \mu \mathrm{g} / \mathrm{ml})$, lincomycin $(25 \mu \mathrm{g} / \mathrm{ml})$, and kanamycin $(5 \mu \mathrm{g} / \mathrm{ml})$. Escherichia coli strain $\mathrm{DH} 5 \alpha\left(\mathrm{F}^{-}\right.$endA1 hsdR17 supE44 $\lambda^{-}$thi-1 recA1 gyrA96 relA1 $\Delta$ (lacZYA-argF) U169 \$80dlac $\Delta($ lacZ)M15; GIBCO-BRL) was used for plasmid constructions. The $3^{\prime}$ end of the spoIIE gene was amplified by PCR from SG38 chromosomal DNA, using the following oligonucleotides: 5'-CAGCTACAGCATGATGGAGC-3' and 5'-CAGCTGTCGACATTGACTACACC3 ' (generating a Sall restriction site). Strains 1301 and 1302 were derived from SG38 by tranformation with plasmid pAF011 or pAF012 selecting for resistance to kanamycin $(5 \mu \mathrm{g} / \mathrm{ml})$, or erythromycin $(1 \mu \mathrm{g} / \mathrm{ml})$ and lincomycin $(25 \mu \mathrm{g} / \mathrm{ml})$, respectively. The $\Omega($ spoIIE::aph-A3)1301 and $\Omega($ spollE::ermC)1302 insertions would result in the addition of 9 and 29 vector amino acids to the truncated SpoIIE protein, respectively. PCR amplification of the spoIIE71 allele was done with chromosomal DNA from strain 71.2 and oligonucleotides $5^{\prime}$-CGTCTAGAGTGCTGGGTACAG-3' igenerating an $\mathrm{Xbal}$ restriction site) and 5'-TATGGTCGACGGAAGCGTTATG-3' (generating a Sall restriction site). The constructed plasmid pAF013 was then tranformed into the wild-type SG38 to check that the mutant allele had been cloned. Double-stranded pAF013 DNA was sequenced directly using a commercial DNA sequencing kit with AmpliTaq DNA polymerase of Perkin Elmer on an automatic DNA sequencer (ABI 373A). In addition to the oligonucleotides used for the PCR, the following oligonucleotides were used for sequencing: 5'-CAACAACAGTCATATCGTC-3' and 5'-CCGTCACTGATTGCTGCAGCATA-3'. A gpr'-'lacZ fusion was introduced into SG38, 1.5, 71.2, 1301, and 1302 by tranformation with plasmid pPS1326 (Sun et al. 1991) and selection for chloramphenicol resistance $(5 \mu \mathrm{g} / \mathrm{ml})$.

\section{General methods}

Solid medium used for growing $B$. subtilis was nutrient agar (Oxoid). Antibiotics or $0.01 \% \mathrm{X}$-gal were added as required. Media for growing Escherichia coli were $2 \times$ TY (Sambrook et al. 1989) and nutrient agar (Oxoid), supplemented with ampicillin $(100 \mu \mathrm{g} / \mathrm{ml})$, as required.

$B$. subtilis cells were made competent for transformation with DNA by the method of Anagnostopoulos and Spizizen (1961), as modified by Jenkinson (1983). B. subtilis chromosomal DNA was prepared by a scaled-down method based on the one described by Errington (1984). DNA manipulations and E. coli tranformations were carried out using standard methods (Sambrook et al. 1989).

$\beta$-Galactosidase activity was measured by the method of Errington and Mandelstam (1986). One unit of $\beta$-galactosidase catalyzes the production of 1 nmole of 4-methylumbelliferone per minute under the standard reaction conditions.
Figure 4. Possible roles for the bifunctional SpoIIE protein in the regulation of $\sigma^{\mathrm{F}}$ activity. In $A-C$, the membrane-associated SpoIIE protein is shown as a circle, which is filled if it is active /in terms of the release of $\sigma^{\mathrm{F}}$ activity by dephosphorylation of SpoIIAA-P) and unfilled if inactive. The protein is shown as being targeted to the sites of incipient asymmetric septa (Arigoni et al. 19951, where it is required for the initiation of septal ingrowth. In $A$ and $B$, the protein is assumed to end up on both sides of the completed septum. In $A$, the phosphatase is active in both compartments; $\sigma^{\mathrm{F}}$ activity is released specifically in the small prespore compartment because the effective concentration of the phosphatase is higher in this compartment. In $B$, the protein is specifically activated in the prespore compartment because of an asymmetry in the septum or a physiological change in the prespore compartment, which is consequent on its unusual morphology or biochemical composition. In $C$, the synthesis of the septum is assumed to require synthesis of considerable amounts of new lipid. This occurs predominantly or exclusively in the large mother cell

compartment, and the resultant flow of new membrane through the closing septal annulus carries with it the SpoiIE protein.
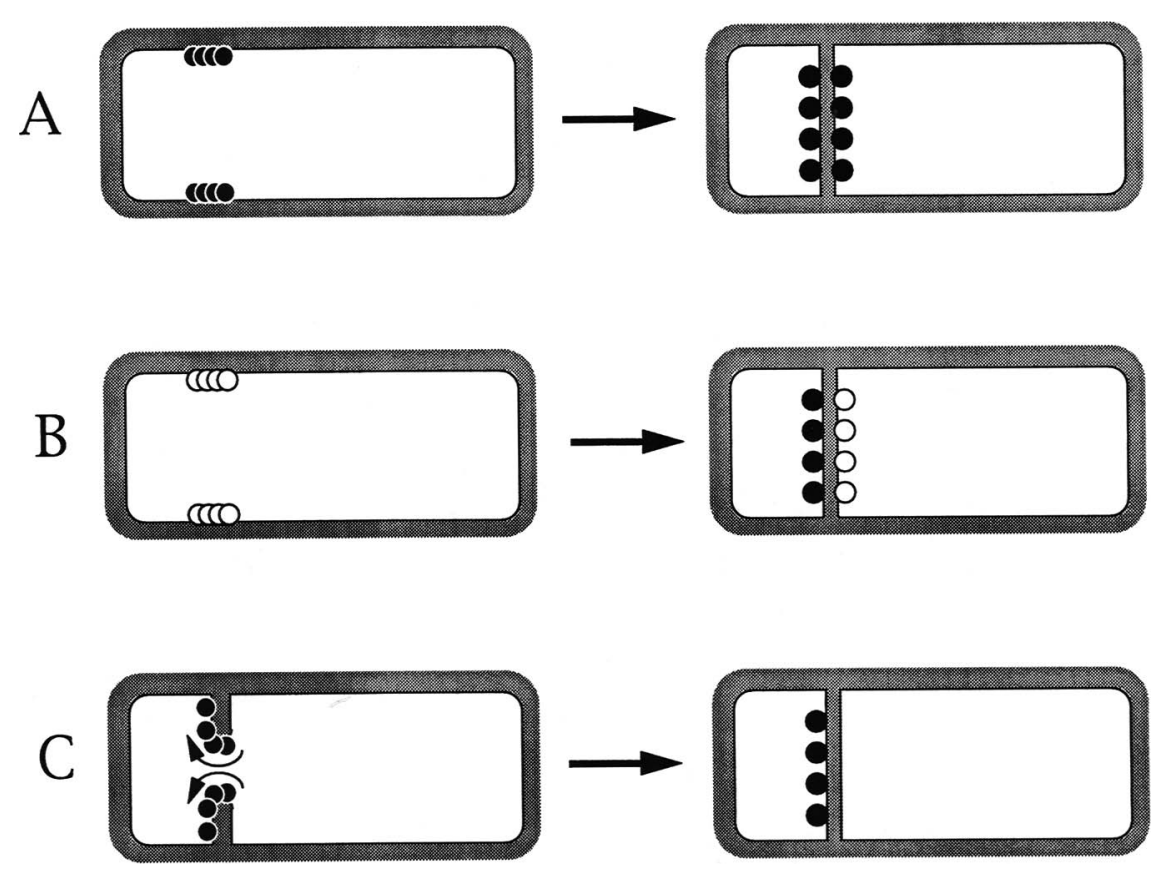
Table 1. B. subtilis strains used

\begin{tabular}{|c|c|c|}
\hline Strain & Genotype & Source/reference \\
\hline SG38 & $\operatorname{trp} C 2$ & Errington and Mandelstam $(1986)$ \\
\hline 1.5 & $\operatorname{trp} C 2$ spoIIAC1 & Errington and Mandelstam (1986) \\
\hline 71.2 & $\operatorname{trpC2}$ spoIIE71 & NG20.12 of Piggot $(1973)$ \\
\hline 690 & $\operatorname{trpC2}$ spoIIAC1 $\Omega$ (spoIIIG'-'lacZ, ermC)687 & Partridge et al. (1991) \\
\hline 693 & $\begin{array}{l}\operatorname{trp} C 2 \Omega(\text { spoIIIG'-'lacZ, ermC)687 } \\
\quad \text { spoIIA::pSGMU624 (P } P_{\mathrm{spac}}-\text { spoIIAABC) }\end{array}$ & Partridge et al. $(1991)$ \\
\hline 1301 & $\operatorname{trp} C 2 \Omega($ spoIIE::aph-A3)1301 & this paper \\
\hline 1302 & $\operatorname{trp} C 2 \Omega($ spoIIE::ermC)1302 & this paper \\
\hline 1303 & $\operatorname{trp} C 2 \Omega\left(\right.$ cat, $P_{x y \Gamma}$ spolIE $)$ & this paper \\
\hline 1304 & $\begin{array}{l}\operatorname{trp} C 2 \Omega(\text { spoIIIG'-'lacZ, ermC)687 } \\
\quad \text { spoIIA::pSGMU624 (P } P_{\mathrm{spac}}-\text { spoIIAABC) } \\
\quad \Omega\left(\text { cat, } P_{\mathrm{xyl}}-\text { spoIIE) }\right.\end{array}$ & this paper \\
\hline \multicolumn{3}{|l|}{ Plasmids } \\
\hline pAF010 & bla, cat, spoIIE(1868-2481) & $\begin{array}{l}\text { 1027-bp PstI-SalI PCR fragment cloned into } \\
\text { PstI-SalI-digested pSG1301 }\end{array}$ \\
\hline pAF01l & bla, cat, $\Omega /$ spoIIE(1868-2481)::aph-A3/1301 & $\begin{array}{l}\text { aph-A3 gene from BamHI-digested pSG } 122 \text { cloned into } \\
\text { the BclI site in the spoIIE insert of pAF010 }\end{array}$ \\
\hline pAF012 & bla, cat, $\Omega /$ spoIIE(1868-2481)::erm C/1302 & $\begin{array}{l}\text { ermC gene from SmaI-digested pSGMU250 inserted into } \\
\text { the end-filled EcoRI site in the spoIIE insert of pAF010 }\end{array}$ \\
\hline pAF013 & bla, cat, spoIIE71(1221-2481) & $\begin{array}{l}\text { 1274-bp PCR fragment from } 71.2 \text { DNA digested with } \\
\text { XbaI and SalI and cloned into XbaI-SalI-digested } \\
\text { pSG1301 }\end{array}$ \\
\hline pPS1326 & bla, cat, gpr'-'lacZ & Sun et al. $(1991)$ \\
\hline pRD96 & bla, cat, $P_{\mathrm{xyl}}$ & R.A. Daniel (unpubl.) \\
\hline pSG122 & bla, aph-A3 & Daniel and Errington (1993) \\
\hline pSG250 & bla, ermc & Partridge et al. (1991) \\
\hline pSG1301 & bla, cat & Stevens et al. (1992) \\
\hline
\end{tabular}

\section{Induction of sporulation}

B. subtilis cells grown in hydrolyzed casein growth media at $37^{\circ} \mathrm{C}$ were induced to sporulate by the resuspension method of Sterlini and Mandelstam (1969), as modified by Partridge and Errington (1993). Times (hours) after resuspension of cells in the starvation medium were denoted $t_{0}, t_{1}$, and so forth.

\section{Measurement of septation by phase-contrast microscopy}

Cell samples $(0.5 \mathrm{ml})$ were fixed immediately and visualized as described by Wu et al. (1995) (but without adding $\mathrm{NaN}_{3}$ to the samples) and the cells were examined directly on a Zeiss Axiophot fluorescence microscope equipped with a $100 \times$ oil immersion objective, a $1.25 \times$ Optovar, a G365 exciter filter, and an LP420 barrier filter. The percentage of asymmetric septa was determined by counting 130-200 cells at each time point. The number of condensed forespore nucleoids was also determined, and this agreed with the number of asymmetric septa. In the wild-type strain SG38, the asymmetric septa begin to disappear after $t_{1}$, as prespore engulfment proceeds; therefore, only the numbers of condensed forespore nucleoids were counted after $t_{1}$.

\section{Electron microscopy}

Samples $(10 \mathrm{ml})$ from sporulating cultures were fixed and sectioned as described previously (Illing and Errington 1991), except that the sections were observed in a Zeiss 912 Omega electron microscope (accelerating voltage $80 \mathrm{kV}$ ) and images were collected with a CCD camera $(1024 \times 1024$ chip; depth 14 bits $)$ and processed by Adobe Photoshop.

\section{Analysis of SpoIIAA and SpolIAA-P levels in vivo}

Samples of cultures $(1 \mathrm{ml})$ were collected by centrifugation $(\mathrm{mi}-$ crocentrifugel, and the cell pellets were stored at $-20^{\circ} \mathrm{C}$. The tubes were tranferred to dry ice, and $500 \mu$ l of cold buffer $[50 \mathrm{~mm}$ Tris, (pH 9), 100 mM EDTA, 40\% glycerol, 15\% Triton X-100, 2 $\mathrm{mg} / \mathrm{ml}$ of lysozyme] was added to each cell pellet. The samples were sonicated three times for $20 \mathrm{sec}$, using a Vibracell VC 300 sonicator with a microtip and at half of the full setting. Phenylmethylsulfonyl fluoride was then added $12 \mathrm{~mm}$ final concentration), and the samples were centrifuged at $4^{\circ} \mathrm{C}$ for $10 \mathrm{~min}$. Bromophenol blue $(0.01 \%$ final concentration) was added to the supernatants, and $30-\mu l$ amounts were separated by nondenaturing polyacrylamide gel electrophoresis (Diederich et al. 1994). The gels were run overnight at $4 \mathrm{~mA}$ after which the proteins were transferred electrophoretically to nitrocellulose filters [160 mA for $2 \mathrm{hr}$ in $20 \mathrm{~mm}$ Tris, $192 \mathrm{~mm}$ glycine (pH 8.3)]. SpoIIAA and SpoIIAA-P were detected by immunoblotting with anti-SpoIIAA IgG (Diederich et al. 1994).

\section{Induction of the spoIIA and spoIIE genes in nonsporulating} cells

Strain 1304 was inoculated into $80 \mathrm{ml}$ of PAB (DIFCO antibiotic medium 3) at an initial $\mathrm{OD}_{600}$ of 0.01 . The culture was grown at $37^{\circ} \mathrm{C}$ until an $\mathrm{OD}_{600}$ of 0.35 was reached. The culture was divided into four aliquots to which were added either no inducer, 
$1 \%$ xylose, $0.3 \mathrm{~mm}$ IPTG, or $1 \%$ xylose plus $0.3 \mathrm{~mm}$ IPTG. Growth and $\beta$-galactosidase activity was followed for $3 \mathrm{hr}$ for each culture. The growth rate $\left(O D_{600}\right)$ showed no significant difference between uninduced and induced cultures.

\section{Acknowledgments}

This work was supported by the Biotechnology and Biological Sciences Research Council and the Medical Research Council. We thank P. Stragier and R. Losick for helpful comments on the manuscript.

The publication costs of this article were defrayed in part by payment of page charges. This article must therefore be hereby marked "advertisement" in accordance with 18 USC section 1734 solely to indicate this fact.

\section{References}

Alper, S., L. Duncan, and R. Losick. 1994. An adenosine nucleotide switch controlling the activity of a cell type-specific transcription factor in B. subtilis. Cell 77: 195-205.

Anagnostopoulos, C. and J. Spizizen. 1961. Requirements for tranformation in Bacillus subtilis. J. Bacteriol. 81: 741-746.

Arigoni, F., K. Pogliano, C.D. Webb, P. Stragier, and R. Losick. 1995. Localization of protein implicated in establishment of cell type to sites of asymmetric division. Science 270: 637640.

Benson, A.K. and W.G. Haldenwang. 1993a. Bacillus subtilis $\sigma^{\mathbf{B}}$ is regulated by a binding protein (RsbW) that blocks its association with core RNA polymerase. Proc. Natl. Acad. Sci. 90: $2330-2334$.

- 1993b. The $\sigma^{\mathrm{B}}$-dependent promoter of the Bacillus subtilis $\operatorname{sig} B$ operon is induced by heat shock. I. Bacteriol. 175: 1929-1935.

Boylan, S.A., A. Rutherford, S.M. Thomas, and C.W. Price. 1992. Activation of Bacillus subtilis transcription factor $\sigma^{\mathrm{B}}$ by a regulatory pathway responsive to stationary-phase signals. $J$. Bacteriol. 174: 3695-3706.

Boylan, S.A., A.R. Redfield, M.S. Brody, and C.W. Price. 1993. Stress induced activation of the $\sigma^{B}$ transcription factor of Bacillus subtilis. J. Bacteriol. 175: 7931-7937.

Cutting, S., V. Oke, A. Driks, R. Losick, S. Lu, and L. Kroos. 1990. A forespore checkpoint for mother cell gene expression during development in B. subtilis. Cell 62: 239-250.

Daniel, R.A. and J. Errington. 1993. Cloning, DNA sequence, functional analysis and transcriptional regulation of the genes encoding dipicolinic acid synthesis required for sporulation in Bacillus subtilis. I. Mol. Biol. 232: 468-483.

Diederich, B., J.F. Wilkinson, T. Magnin, S.M.A. Najafi, J. Errington, and M.D. Yudkin. 1994. Role of interactions between SpoIIAA and SpoIIAB in regulating cell-specific transcription factor $\sigma^{\mathrm{F}}$ of Bacillus subtilis. Genes \& Dev. 8: $2653-2663$.

Dufour, A. and W.G. Haldenwang. 1994. Interactions between a Bacillus subtilis anti-o factor (RsbW) and its antagonist (RsbV). J. Bacteriol. 176: 1813-1820.

Duncan, L. and R. Losick. 1993. SpoIIAB is an anti- $\sigma$ factor that binds to and inhibits transcription by regulatory protein $\sigma^{\mathrm{F}}$ from Bacillus subtilis. Proc. Natl. Acad. Sci. 90: 2325-2329.

Duncan, L., S. Alper, F. Arigoni, R. Losick, and P. Stragier. 1995. Activation of cell-specific transciption by a serine phosphatase at the site of asymmetric division. Science 270: 64l644.

Errington, J. 1984. Efficient Bacillus subtilis cloning system using bacteriophage vector $\phi 105 \mathrm{~J} 9$. I. Gen. Microbiol. 130: $2615-2628$.
1993. Bacillus subtilis sporulation: Regulation of gene expression and control of morphogenesis. Microbiol. Rev. 57: $1-33$.

_- 1996. Determination of cell fate in Bacillus subtilis. Trends Genet. 12: 31-34.

Errington, J. and J. Mandelstam. 1986. Use of a lacZ gene fusion to determine the dependence pattern of sporulation operon spollA in spo mutants of Bacillus subtilis. J. Gen. Microbiol. 132: $2967-2976$.

Errington, J., A. Feucht, P.J. Lewis, M. Lord, T. Magnin, S.M.A. Najafi, J.F. Wilkinson, and M.D. Yudkin. 1996. Control of the cell-specificity of $\sigma^{\mathrm{F}}$ activity in Bacillus subtilis. Phil. Trans. Royal. Soc. (in press).

Gholamhoseinian, A. and P.J. Piggot. 1989. Timing of spoII gene expression relative to septum formation during sporulation of Bacillus subtilis. J. Bacteriol. 171: 5747-5749.

Hauser, P.M. and J. Errington. 1995. Characterization of cell cycle events during the onset of sporulation in Bacillus subtilis. J. Bacteriol. 177: 3923-3931.

Horvitz, H.R. and I. Herskowitz. 1992. Mechanisms of asymmetric cell division: Two Bs or not two Bs, that is the question. Cell 68: 237-255.

Illing, N. and J. Errington. 1991. Genetic regulation of morphogenesis in Bacillus subtilis: Roles of $\sigma^{\mathrm{E}}$ and $\sigma^{\mathrm{F}}$ in prespore engulfment. I. Bacteriol. 173: 3159-3169.

Jenkinson, H.F. 1983. Altered arrangement of proteins in the spore coat of a germination mutant of Bacillus subtilis. $/$. Gen. Microbiol. 129: 1945-1958.

Karow, M.L., P. Glaser and P.J. Piggot. 1995. Identification of a gene, spoIIR, that links the activation of $\sigma^{\mathrm{E}}$ to the transcriptional activity of $\sigma^{\mathrm{F}}$ during sporulation in Bacillus subtilis. Proc. Natl. Acad. Sci. 92: 2012-2016.

Lewis, P.J., S.R. Partridge, and J. Errington. 1994. o factors, asymmetry, and the determination of cell fate in Bacillus subtilis. Proc. Natl. Acad. Sci. 91: 3849-3853.

Londoño-Vallejo, J.-A. and P. Stragier. 1995. Cell-cell signaling pathway activating a developmental transcription factor in Bacillus subtilis. Genes \& Dev. 9: 503-508.

Losick, R. and P. Stragier. 1992. Crisscross regulation of celltype-specific gene expression during development in $B$. subtilis. Nature 355: 601-604.

Magnin, T., M. Lord, J. Errington, and M.D. Yudkin. 1996. Establishing differential gene expression in sporulating Bacillus subtilis: Phosphorylation of SpoIIAA (anti-anti- $\sigma^{\mathrm{F}}$ ) alters its conformation and prevents formation of a SpoIIAA/SpoIIAB/ADP complex. Mol. Microbiol. 19: 901-907.

Margolis, P. 1993. "Establishment of cell type during sporulation in Bacillus subtilis." Ph.D. thesis, Harvard University, Cambridge, MA.

Margolis, P., A. Driks, and R. Losick. 1991. Establishment of cell type by compartmentalized activation of a transcription factor. Science 254: 562-565.

Min, K.-T., C.M. Hilditch, B. Diederich, J. Errington, and M.D. Yudkin. 1993. $\sigma^{\mathrm{F}}$, the first compartment-specific transcription factor of $B$. subtilis, is regulated by an anti- $\sigma$ factor that is also a protein kinase. Cell 74: 735-742.

Partridge, S.R. and J. Errington. 1993. The importance of morphological events and intercellular interactions in the regulation of prespore-specific gene expression during sporulation in Bacillus subtilis. Mol. Microbiol. 8: 945-955.

Partridge, S.R., D. Foulger, and J. Errington. 1991. The role of $\sigma^{\mathrm{F}}$ in prespore-specific transcription in Bacillus subtilis. Mol. Microbiol. 5: 757-767.

Piggot, P.J. 1973. Mapping of asporogenous mutations of Bacillus subtilis: A minimum estimate of the number of sporulation operons. J. Bacteriol. 114: 1241-1253. 
Piggot, P.J. and J.G. Coote. 1976. Genetic aspects of bacterial endospore formation. Bacteriol. Rev. 40: 908-962.

Pogliano, K., E. Harry, and R. Losick. 1995. Visualization of the subcellular location of sporulation proteins in Bacillus subtilis using immunofluorescence microscopy. Mol. Microbiol. 18: 459-470.

Sambrook, J., E.F. Fritsch, and T. Maniatis. 1989. Molecular cloning: A laboratory manual. Cold Spring Harbor Laboratory Press, Cold Spring Harbor, NY.

Schmidt, R., P. Margolis, L. Duncan, R. Coppolecchia, C.P. Moran Jr., and R. Losick. 1990. Control of developmental transcription factor $\sigma^{\mathrm{F}}$ by sporulation regulatory proteins SpoIIAA and SpoIIAB in Bacillus subtilis. Proc. Natl. Acad. Sci. 87: 9221-9225.

Sterlini, J.M. and J. Mandelstam. 1969. Committment to sporulation in Bacillus subtilis and its relationship to the development of actinomycin resistance. Biochem. J. 113: 29-37.

Stevens, C.M., R. Daniel, N. Illing, and J. Errington. 1992. Characterization of a sporulation gene, spoIVA, involved in spore coat morphogenesis in Bacillus subtilis. I. Bacteriol. 174: 586-594.

Stragier, P. 1992. Establishment of forespore-specific gene expression during sporulation of Bacillus subtilis. In Prokaryotic structure and function: A new perspective (ed. S. Mohan, C. Dow, and J.A. Cole), pp. 297-310. Cambridge University Press, Cambridge, UK.

Sun, D., P. Fajardo-Cavazos, M.D. Sussman, F. Tovar-Rojo, R.M. Cabrera-Martinez, and P. Setlow. 1991. Effect of chromosome location of Bacillus subtilis forespore genes on their spo gene dependence and transcription by $\mathrm{E \sigma}^{\mathrm{F}}$ : Identification of features of good $\mathrm{E \sigma}^{\mathrm{F}}$-dependent promoters. I. Bacteriol. 173: 7867-7874.

Völker, U., S. Engelmann, B. Maul, S. Riethdorf, A. Völker, R. Schmid, H. Mach, and M. Hecker. 1994. Analysis of the induction of general stress proteins of Bacillus subtilis. Microbiology 140: 741-752.

Völker, U., A. Dufour, and W.G. Haldenwang. 1995. The Bacillus subtilis rsbU gene product is necessary for RsbX-dependent regulation of $\sigma^{\mathrm{B}}$. J. Bacteriol. 177: 114-122.

Wise, A.A. and C.W. Price. 1995. Four additional genes in the $\operatorname{sig} B$ operon of Bacillus subtilis that control activity of the general stress factor $\sigma^{\mathrm{B}}$ in response to environmental signals. J. Bacteriol. 177: 123-133.

Wu, L.J., P.J. Lewis, R. Allmansberger, P.M. Hauser, and J. Errington. 1995. A conjugation-like mechanism for prespore chromosome partitioning during sporulation in Bacillus subtilis. Genes \& Dev. 9: 1316-1326.

Yudkin, M.D. 1987. Structure and function in a Bacillus subtilis sporulation-specific sigma factor: Molecular nature of mutations in spoIIAC. J. Gen. Microbiol. 133: 475-481. 


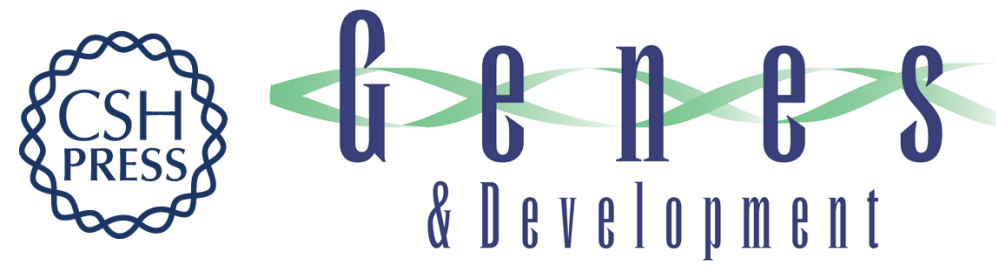

\section{Bifunctional protein required for asymmetric cell division and cell-specific transcription in Bacillus subtilis.}

A Feucht, T Magnin, M D Yudkin, et al.

Genes Dev. 1996, 10:

Access the most recent version at doi:10.1101/gad.10.7.794

References This article cites 43 articles, 27 of which can be accessed free at: http://genesdev.cshlp.org/content/10/7/794.full.html\#ref-list-1

License

Email Alerting

Service

Receive free email alerts when new articles cite this article - sign up in the box at the top right corner of the article or click here.

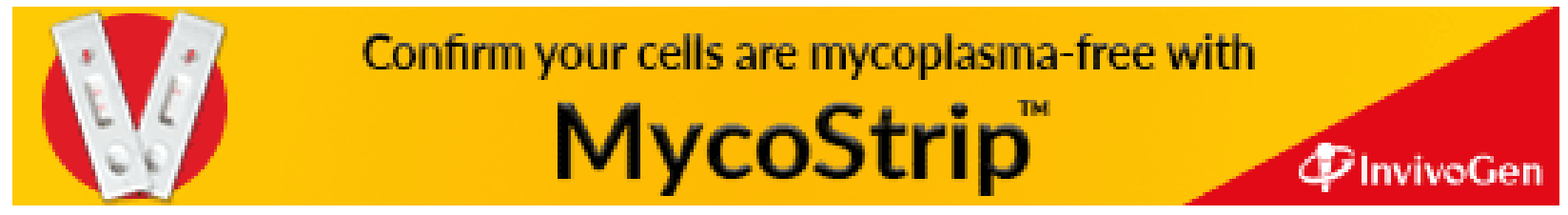

